\title{
Psychological Impact, Coping Among College Students using Social Networking Sites: A Comparative Study
}

\author{
Rupa Sanadi \\ Psychiatric Social Worker \\ Department of Psychiatric Social Work, \\ National Institute of Mental Health and Neuro Sciences, \\ Bangalore, India
}

\author{
Dr. R. Dhanasekhar Pandian \\ Professor and Head of the Department, \\ Department of Psychiatric Social Work, \\ National Institute of Mental Health and Neuro Sciences, \\ Bangalore, India
}

\begin{abstract}
Social networking sites give a good platform for discussion on various topics and issues and that helps to do messaging, blogging, sharing photos, audio \& videos and generates for social interaction, making dialogues and exchange their thoughts and views. Especially youngsters recognized as Igeneration, who are the keen users of social media. The current social media revolution is impacting on demonstrating the changing mindset of the youth. The aim of the study was to understand the positive and negative effect, psychological impact and coping among college students and comparing between the genders which are using social networking sites. The purposive sampling method was used for recruitment of 100 undergraduate students $($ male $=50$, female $=50)$ from the degree college of Bangalore urban. Semi-structured questionnaires and selfreported standardized inventory has been used for the data collection. Study reveals that male students are more users than female students, and a mild level of psychological distress was found in the higher number of users. And it also concluded that there was both positive and negative impact of social networking sites usages among the college students and male students are more users and prone to get addicted as well. Male students are found psychologically distressed but in terms of adopting coping styles, there were no differences among both respondents using social networking sites.
\end{abstract}

Keywords: College students, Social Network Sites, Psychological Impact and Coping style.

\section{INTRODUCTION}

Social networking services utilize the technology and software tools to facilitate communication and interaction between members. A social networking site (SNS) may also know as a social website or social media. Social media are the platforms that enable the interactive web by engaging users to participate in, comment on and create content as means of communicating with their social graph, other users, and the public [4]. Many of the young adults use social media networks to communicate with family, friends, and strangers, some may use for academic and educational purposes. Members use these tools to share online ideas, documents, photos, videos, and favorite websites almost anything [17]. The social networking site has become daily life part of fashionable people and these websites are immensely popular among the youth and they contribute the majority percentage of the users. In general, most prolific users of social media are young under 25, when it comes to creating, updating, and viewing social media [25]. The study found that most of the college students have a social media profile using at least once a day [19]. Some of the pathological users reported more perceived academic, social, and interpersonal problems as well as lower self-esteem [27].

Psychological distress is like an emotional disturbance that can impact on the day-to-day life of individuals. The relationships between Internet addiction and perceived impact on academics, daily life routines, and relationships with friends, family, and teachers among college students [6]. It is a positive indicator that Indian youth are not only techno-savvy and socially active, but they also possess social consciousness [26]. Youths and adolescents are at some risk as they navigate and experiment with social media because of their limited capacity for self-regulation and susceptibility to peer pressure. There are frequent online expressions of offline behaviours, as clique-forming, harassment, and sexual testing according to recent research [20]. Cyberbullying is quite common, can occur to any young person online, and can cause profound psychosocial problems/issues including depression, anxiety, severe isolation and tragically suicide [10]. The study was intended to clarify the psychological literature concerning the use of the Internet and its effect on social engagement in a college-aged population with attention to levels of social anxiety and depression. In a more recent study of Taiwanese college students found that major depression was related to addiction, but only for men [15].

There is a study reported problems of addiction included: experienced academic problems, unable to control Internet use, spent limited time with real people in their lives, avoided daily chores, faced finical debt for the Internet fee, and jeopardized their marriage status from online romance. He had concluded that the Internet itself is not addictive but specific applications play a significant role in the development of pathological problems among users [38]. There was a negative attitude toward social media when college students used them. Eighty percent of the sample admitted that they posted or responded while completing homework. It has affected their efficiencies and their grades. For instance, imagine one student spent over six hours checking social media sites and responded while completing their homework; it would be likely increase distraction of the students which can be detrimental to student performance [37]. The study findings indicate that electronic media use is negatively associated with grades. It also found that about two-thirds of the students reported using electronic media while in class, studying, or doing homework. This 
multitasking likely increases distraction, something prior research has shown to be detrimental to student performance [12].

As social media websites, such as Facebook, YouTube, and Twitter gain popularity, they are also are becoming increasingly dangerous as they create modes to procrastinate while trying to complete homework. Hence, in a survey of 102 students, $57 \%$ stated that social media has made them less productive. The relationship between social media and grades, a study released by Ohio State University reveals that college students who utilize Facebook spend less time studying and have lower grades than students who do not use the popular social networking sites [14]. Relationships with family and friends have a large influence on health and well-being and social support can help to diminish the negative effects of stressful life events of college students [32]. The Internet is a source of coping to escape from problems or stressors [1]. In the current scenario, most of the young generation is influenced by various social networking sites due to their day to day functions, services, and applications. Social networking sites have both negative and positive impacts on youth [17]. Youth especially, college students are attracted towards social sites due to various features. The many research studies show that social networking sites are the psychological impact on users and helping as a support agent in stressful situations and there are fewer studies on psychological distress of using sites and coping to reduce the distress. The research examined potential associations among perceived stress, time spent on the Internet, underlying motives for engaging in Internet use, problematic Internet use, and traditional approaches to coping. Avoidant emotional coping was significantly and positively associated with perceived stress. In contrast, active emotionfocused coping emerged as a negative predictor of perceived stress and problem-focused coping was not a predictor of stress [7].

\section{METHODOLOGY}

Social networking websites are immensely popular among the youth and many research studies show that there are huge positive and negative impacts on the youth who uses Social Networking Sites (SNS). So, the researcher wanted to study the psychological impact of these social networking sites on college students and how they are coping up.

\section{Objectives of the study:}

- To explore the socio-demographic details of the respondents and related factors to the usage of social networking sites

- To explore the positive and negative effects of using SNS

- To understand the psychological distress and coping strategies of using SNS

- To compare the gender differences of using SNS

- To understand the relationship between psychological distress and coping styles of using SNS among both genders of college students

\section{Hypothesis:}

- Significant difference in psychological distress among college students using SNS

- $\quad$ Significant difference in coping skills among college students using SNS.

- Significant difference in psychological distress and coping skills among college students based on gender using SNS

\section{Data collection:}

The descriptive research design was adopted for an understanding of the proposed quantitative research objectives. And the purposive sampling method has been used effectively. Semi-structured questionnaires for collecting socio-demographic details and other factors related to the usage of social networking sites and self-inventory instruments, DASS (42 items) and Brief Cope (28 items) were used for the data collection. A survey was conducted in undergraduate college of Bangalore urban district wherein 300 samples were screened among 100 active users have been recruited for study and divided each gender equally. All questionnaires were filled and reciprocated enthusiastically by the respondents.

\section{Data analysis:}

SPSS (statistical package for social sciences) version 22.0, used for data transformation and data was analyzed using specific statistical tools. Shapiro-Wilk test was used to test normality for the obtained data. Since the data variable does not follow a normal distribution, a non-parametric test was used to analyze the data. The descriptive statistics such as median, range, and frequency distribution were used to describe the socio-demographic variables and the other study variables. The non-parametric statistical tests such as MannWhitney U Test was used to identify the differences between the variables.

\section{RESULTS}

\section{Section 1: Socio-demographic profile of the respondents:}

Since the age of the respondents is not following a normal distribution, the median and range are used as the statistical inferences.

The table 1.1 describes that, Majority of the respondent i.e. $95 \%$ belongs to urban domicile among both genders wherein $51.5 \%$ are male and $48.4 \%$ are female. Majority of the respondent i.e. $71 \%$ belongs to Hindu religion among both genders wherein $53.5 \%$ are female and $46.4 \%$ are male. In terms of family size, majority of the respondent i.e. $58 \%$ belongs to less than 4 members wherein $51.7 \%$ are male and $48.2 \%$ are female. With respective of family monthly income, majority of the respondents i.e $42 \%$ belong to less than Rs.50000 of monthly income wherein $52.3 \%$ are male and $47.6 \%$ are female. 
Table 1.1: Socio-demographic details of the respondents

\begin{tabular}{|c|c|c|c|c|c|c|c|c|}
\hline \multirow{3}{*}{$\begin{array}{l}\mathrm{Sl} \\
\mathrm{N} \\
\mathrm{o}\end{array}$} & \multirow{3}{*}{ Variables } & \multirow{3}{*}{ Attribute } & \multicolumn{4}{|c|}{ Gender } & \multirow{2}{*}{\multicolumn{2}{|c|}{ Total }} \\
\hline & & & \multicolumn{2}{|c|}{ Male } & \multicolumn{2}{|c|}{ Female } & & \\
\hline & & & $\begin{array}{l}\mathrm{N}= \\
50\end{array}$ & $\%$ & $\begin{array}{l}\mathrm{N}= \\
50\end{array}$ & $\%$ & $\begin{array}{l}\mathrm{N}= \\
100\end{array}$ & $\%$ \\
\hline 1 & Age & \multicolumn{5}{|l|}{ years } & 20 & $8-24)$ \\
\hline \multirow{2}{*}{2} & \multirow{2}{*}{ Domicile } & Urban & 49 & $\begin{array}{l}51 . \\
5\end{array}$ & 46 & $\begin{array}{l}48 . \\
4\end{array}$ & 95 & 95 \\
\hline & & Rural & 01 & 20 & 04 & 80 & 05 & 05 \\
\hline \multirow{4}{*}{3} & \multirow{4}{*}{ Religion } & Hindu & 33 & $\begin{array}{l}46 . \\
4\end{array}$ & 38 & $\begin{array}{l}53 . \\
5\end{array}$ & 71 & 71 \\
\hline & & Muslim & 12 & $\begin{array}{l}63 . \\
1\end{array}$ & 07 & $\begin{array}{l}36 . \\
8\end{array}$ & 19 & 19 \\
\hline & & $\begin{array}{l}\text { Christia } \\
\text { n }\end{array}$ & 04 & 50 & 04 & 50 & 08 & 08 \\
\hline & & Other & 01 & 50 & 01 & 50 & 02 & 02 \\
\hline \multirow[t]{3}{*}{4} & \multirow{3}{*}{$\begin{array}{l}\text { Family } \\
\text { Size }\end{array}$} & $<4$ & 30 & $\begin{array}{l}51 . \\
7\end{array}$ & 28 & $\begin{array}{l}48 . \\
2\end{array}$ & 58 & 58 \\
\hline & & $5-10$ & 16 & $\begin{array}{l}44 . \\
4\end{array}$ & 20 & $\begin{array}{l}55 . \\
5\end{array}$ & 36 & 36 \\
\hline & & $>10$ & 04 & $\begin{array}{l}66 . \\
6\end{array}$ & 02 & $\begin{array}{l}33 . \\
3\end{array}$ & 06 & 06 \\
\hline \multirow[t]{5}{*}{5} & \multirow{5}{*}{$\begin{array}{l}\text { Family } \\
\text { Monthly } \\
\text { Income }\end{array}$} & $<50,000$ & 22 & $\begin{array}{l}52 . \\
3\end{array}$ & 20 & $\begin{array}{l}47 . \\
6\end{array}$ & 42 & 42 \\
\hline & & $\begin{array}{l}50,001 \\
-1 \text { lakh }\end{array}$ & 15 & $\begin{array}{l}36 . \\
5\end{array}$ & 26 & $\begin{array}{l}63 . \\
4\end{array}$ & 41 & 41 \\
\hline & & $\begin{array}{l}1,00,001 \\
- \\
1,50,000\end{array}$ & 04 & 80 & 01 & 20 & 05 & 05 \\
\hline & & $\begin{array}{l}1,50,001 \\
-2 \text { lakhs }\end{array}$ & 03 & 60 & 02 & 40 & 05 & 05 \\
\hline & & $\begin{array}{l}> \\
\text { lakhs }\end{array}$ & 06 & $\begin{array}{l}85 . \\
7\end{array}$ & 01 & $\begin{array}{l}14 . \\
2\end{array}$ & 07 & 07 \\
\hline
\end{tabular}

\section{Section 2: Usage of Social Networking Sites and other} related factors:

The table 2.1(1) shows the duration of usage of SNS by the respondents. Majority i.e. 59\% of the respondents are using in the last 4-6 years among both genders wherein $57.6 \%$ are male and $42.3 \%$ are female users.

Table 2.1(1): Duration of usage of Social Networking Sites by the respondents

\begin{tabular}{|l|l|l|l|l|l|l|}
\hline \multirow{3}{*}{$\begin{array}{l}\text { S1 } \\
\text { No }\end{array}$} & \multirow{2}{*}{$\begin{array}{l}\text { Duration of usage of } \\
\text { SNS }\end{array}$} & \multicolumn{4}{|c|}{ Gender } & \multirow{3}{*}{ Total } \\
\cline { 3 - 6 } & & Male & Female & \\
\cline { 3 - 6 } & & $\mathrm{N}$ & $\%$ & $\mathrm{~N}$ & $\%$ & \\
\hline 1 & 1 year -3 years & 10 & 33.3 & 20 & 66.7 & 30 \\
\hline 2 & 4 years -6 years & 34 & 57.6 & 25 & 42.3 & 59 \\
\hline 3 & 7 + years & 06 & 54.5 & 05 & 45.4 & 11 \\
\hline
\end{tabular}

The table 2.1(2) shows how often respondents are using various social networking sites. Majority i.e. $82 \%$ of the respondents use social networking sites every day by both genders equally i.e. $50 \%$.

Table 2.1(2): Frequency of usage of social networking sites

\begin{tabular}{|c|c|c|c|c|c|c|}
\hline \multirow{3}{*}{$\frac{i}{z_{n}}$} & \multirow{3}{*}{$\begin{array}{l}\text { Frequency of usage of } \\
\text { social networking sites }\end{array}$} & \multicolumn{4}{|c|}{ Gender } & \multirow{3}{*}{ Total } \\
\hline & & \multicolumn{2}{|c|}{ Male } & \multicolumn{2}{|c|}{ Female } & \\
\hline & & $\mathrm{N}$ & $\%$ & $\mathrm{~N}$ & $\%$ & \\
\hline 1 & Every day & 41 & 50.0 & 41 & 50.0 & 82 \\
\hline 2 & $2-4$ times in a week & 07 & 46.6 & 08 & 53.3 & 15 \\
\hline & Once in 15 days & 02 & 66.6 & 01 & 33.3 & 03 \\
\hline
\end{tabular}

The table 2.1(3) shows how respondents are spending time on social networking sites. The majority i.e. $79 \%$ of the respondents are spending less than 2 hours wherein $54.4 \%$ are female and $45.5 \%$ are male.

Table 2.1(3): Time spend on usage of social networking sites

\begin{tabular}{|l|l|l|l|l|l|l|}
\hline \multirow{2}{*}{$\begin{array}{l}\text { S1 } \\
\text { No }\end{array}$} & \multirow{2}{*}{$\begin{array}{l}\text { Time spend on usage } \\
\text { social networking sites }\end{array}$} & \multicolumn{4}{|c|}{ Gender } & \multirow{2}{*}{ Total } \\
\cline { 3 - 6 } & & Male & \multicolumn{2}{l|}{ Female } & \\
\cline { 3 - 6 } & & N & $\%$ & N & $\%$ & \\
\hline 1 & $<2$ hours & 36 & 45.5 & 43 & 54.4 & 79 \\
\hline 2 & 2 hours to 4 hours & 08 & 66.6 & 04 & 33.3 & 12 \\
\hline 3 & $>4$ hours & 06 & 66.6 & 03 & 33.3 & 09 \\
\hline
\end{tabular}

The table 2.1(4) depicts the different purposes of usages of SNS. Majority i.e. $87 \%$ of the respondents are using social networking sites for the friendly communication wherein $52.8 \%$ are male and $47.1 \%$ are female followed by $84 \%$ for chatting wherein $54.7 \%$ are male and $45.2 \%$ are female, and followed by $65 \%$ for entertainment wherein $56.9 \%$ are male and $43.1 \%$ are female, $59 \%$ for sharing photos \& to find information wherein $55.9 \%$ are male and $44.1 \%$ are female respectively and $51 \%$ for sharing photos \& picture etc. wherein $50.9 \%$ are male and $49 \%$ are female. However, in overall, majority of the male respondents uses the social networking sites for different purpose compare to female respondents.

Table 2.1(4): Reasons for using social networking sites

\begin{tabular}{|l|l|l|l|l|l|l|}
\hline \multirow{2}{*}{$\begin{array}{l}\text { S1 } \\
\text { No }\end{array}$} & \multirow{2}{*}{$\begin{array}{l}\text { Reasons for using } \\
\text { social networking } \\
\text { sites }\end{array}$} & \multicolumn{4}{|c|}{ Gender } & \multirow{2}{*}{\begin{tabular}{c} 
जale \\
\cline { 3 - 6 }
\end{tabular}} \\
\cline { 2 - 6 } & & $\mathrm{N}$ & $\%$ & $\mathrm{~N}$ & $\%$ & \\
\hline 1 & $\begin{array}{l}\text { Friendly } \\
\text { communication }\end{array}$ & 46 & 52.8 & 41 & 47.1 & 87 \\
\hline 2 & Chatting & 46 & 54.7 & 38 & 45.2 & 84 \\
\hline 3 & $\begin{array}{l}\text { Academic } \\
\text { communication }\end{array}$ & 26 & 63.4 & 15 & 36.5 & 41 \\
\hline 4 & $\begin{array}{l}\text { To discuss new } \\
\text { ideas }\end{array}$ & 22 & 57.8 & 16 & 42.1 & 38 \\
\hline 5 & $\begin{array}{l}\text { To publish } \\
\text { writings }\end{array}$ & 08 & 50.0 & 08 & 50.0 & 16 \\
\hline 6 & $\begin{array}{l}\text { To discuss social } \\
\text { issues }\end{array}$ & 19 & 59.3 & 13 & 40.6 & 32 \\
\hline 7 & $\begin{array}{l}\text { To promote for } \\
\text { work }\end{array}$ & 12 & 63.1 & 07 & 36.8 & 19 \\
\hline 8 & Instant message & 24 & 55.8 & 19 & 44.1 & 43 \\
\hline 9 & $\begin{array}{l}\text { To meet new } \\
\text { people }\end{array}$ & 34 & 70.8 & 14 & 29.1 & 48 \\
\hline 10 & $\begin{array}{l}\text { To find } \\
\text { information }\end{array}$ & 33 & 55.9 & 26 & 44.1 & 59 \\
\hline 11 & $\begin{array}{l}\text { Sharing } \\
\text { information }\end{array}$ & 26 & 54.1 & 22 & 45.8 & 48 \\
\hline 12 & $\begin{array}{l}\text { Seminar/Conferenc } \\
\text { es }\end{array}$ & 08 & 61.5 & 05 & 38.4 & 13 \\
\hline 13 & Sharing photos & 33 & 55.9 & 26 & 44.1 & 59 \\
\hline 14 & Entertainment & 37 & 56.9 & 28 & 43.1 & 65 \\
\hline 15 & $\begin{array}{l}\text { Sharing video and } \\
\text { pictures }\end{array}$ & 26 & 50.9 & 25 & 49.0 & 51 \\
\hline & & & & & \\
\hline
\end{tabular}


The table 2.1(4) shows the various kinds of problems faced by the respondents while using social networking sites. Majority respondent i.e. $38 \%$ are reported that they had faced problem of lack of technical knowledge wherein $55.2 \%$ are female and $44.7 \%$ are male followed by $27 \%$ of respondents reported lack of security and any others wherein $55.5 \%$ are male and $44.4 \%$ are female respectively, $23 \%$ of respondents expressed not user friendly wherein $60.8 \%$ are male and $39.1 \%$ are female and $22 \%$ reported lack of privacy wherein both genders shared equally i.e. $50 \%$.

Table 2.1(4): Problems faced by the respondents using social networking sites

\begin{tabular}{|l|l|l|l|l|l|l|}
\hline \multirow{2}{*}{$\begin{array}{l}\text { S1 } \\
\text { No }\end{array}$} & \multicolumn{4}{|c|}{$\begin{array}{l}\text { Problems faced by the } \\
\text { respondents using } \\
\text { social networking sites }\end{array}$} & \multicolumn{4}{|c|}{ Male } & \multirow{2}{*}{ Total } \\
\cline { 3 - 6 } & $\mathrm{N}$ & $\%$ & $\mathrm{~N}$ & $\%$ & \\
\hline 1 & Lack of security & 15 & 55.5 & 12 & 44.4 & 27 \\
\hline 2 & Lack of privacy & 11 & 50 & 11 & 50 & 22 \\
\hline 3 & Not user friendly & 14 & 60.8 & 09 & 39.1 & 23 \\
\hline 4 & Poor internet connectivity & 02 & 33.3 & 04 & 66.6 & 06 \\
\hline 5 & $\begin{array}{l}\text { Lack of technical } \\
\text { knowledge }\end{array}$ & 17 & 44.7 & 21 & 55.2 & 38 \\
\hline 6 & $\begin{array}{l}\text { Non-availability of full- } \\
\text { fledged Internet facility }\end{array}$ & 02 & 33.3 & 04 & 66.6 & 06 \\
\hline 7 & $\begin{array}{l}\text { Fear of misusing personnel } \\
\text { information }\end{array}$ & 02 & 50 & 02 & 50 & 04 \\
\hline 8 & Any other & 15 & 55.5 & 12 & 44.4 & 27 \\
\hline
\end{tabular}

The table 2.1(5) shows about negative experiences of the respondents while using social networking sites. $30 \%$ of the respondents reported that they had negative experiences while using social networking sites wherein $56.6 \%$ are male and $43.3 \%$ are female.

Table 2.1(5): Negative experiences of using SNS

\begin{tabular}{|l|l|l|l|l|l|l|}
\hline \multirow{2}{*}{$\begin{array}{l}\text { S1 } \\
\text { No }\end{array}$} & \multirow{2}{*}{$\begin{array}{l}\text { Negative } \\
\text { experiences while } \\
\text { using SNS }\end{array}$} & \multicolumn{3}{|l|}{ Gender } & \multirow{2}{*}{ Total } \\
\cline { 3 - 6 } & & \multicolumn{2}{|l|}{ Male } & \multicolumn{2}{|l|}{ Female } & \\
\cline { 3 - 6 } & & $\mathrm{N}$ & $\%$ & $\mathrm{~N}$ & $\%$ & \\
\hline 1 & Yes & 17 & 56.6 & 13 & 43.3 & 30 \\
\hline 2 & No & 33 & 47.1 & 37 & 52.8 & 70 \\
\hline
\end{tabular}

Section 3: Psychological distress levels of the respondents:

The table 3.1 depict the median and range of the respondents based on their level of Depression, Anxiety, and Stress. It indicates that male respondents experienced a mild level of depression compared to female respondents. Regarding the anxiety, male respondents experienced a moderate level of anxiety compared to female respondents. Subsequently, about the stress, where the mild level of stress was experienced by male respondents compared to the female respondents. The Mann Whitney $\mathrm{U}$ test computed for these were found to be statistically significant (Depression- $\mathrm{p}=0.045^{*}$, Anxiety$\mathrm{p}=0.023^{*}$ and Stress- $\left.\mathrm{p}=0.049^{*}\right)$ differences among the respondents.
Table 3.1: Level of Depression, Anxiety and Stress of the respondents

\begin{tabular}{|c|c|c|c|c|c|c|}
\hline \multirow{3}{*}{$\frac{\frac{0}{0}}{\frac{\pi}{3}}$} & \multicolumn{4}{|c|}{ Gender } & \multirow{3}{*}{ 光㐫芯导 } & \multirow{3}{*}{$\frac{\mathscr{O}}{\stackrel{\pi}{J}}$} \\
\hline & \multicolumn{2}{|c|}{ Male } & \multicolumn{2}{|c|}{ Female } & & \\
\hline & Median & Range & Median & Range & & \\
\hline $\begin{array}{l}\text { Depressi } \\
\text { on }\end{array}$ & $\begin{array}{c}11 . \\
5000\end{array}$ & $\begin{array}{l}1.00- \\
33.00\end{array}$ & $\begin{array}{c}9 . \\
0000\end{array}$ & $\begin{array}{l}0.00- \\
32.00\end{array}$ & $\begin{array}{c}959 . \\
000\end{array}$ & $\begin{array}{c}0.045 \\
*\end{array}$ \\
\hline Anxiety & $\begin{array}{c}10 . \\
5000\end{array}$ & $\begin{array}{l}1.00- \\
29.00\end{array}$ & $\begin{array}{c}7 . \\
0000\end{array}$ & $\begin{array}{l}0.00- \\
27.00\end{array}$ & $\begin{array}{l}919 . \\
500\end{array}$ & $\begin{array}{c}0.023 \\
*\end{array}$ \\
\hline Stress & $\begin{array}{c}14 . \\
5000\end{array}$ & $\begin{array}{l}2.00- \\
31.00\end{array}$ & $\begin{array}{c}12 . \\
0000\end{array}$ & $\begin{array}{l}2.00- \\
33.00\end{array}$ & $\begin{array}{l}965 . \\
000\end{array}$ & $\begin{array}{c}0.049 \\
*\end{array}$ \\
\hline
\end{tabular}

Level of Significance: $*=0.05, * *=0.01$ and $* * *=0.001$

\section{Section 4: Coping behaviours of the respondents:}

The below table 4.1 indicates that the different coping methods adopted by the respondents. The median and range differences in coping styles were studied among the male and female respondents separately, further Mann-Whitney $U$ test used to find a significant difference among male and female respondents. It was found that male and female respondents do not have a significant difference in adopting their coping behaviour.

Table 4.1: The various coping strategies of the respondents

\begin{tabular}{|c|c|c|c|c|c|c|}
\hline $\begin{array}{l}\text { S1. } \\
\text { No }\end{array}$ & $\begin{array}{l}\text { Coping } \\
\text { Domains }\end{array}$ & Gender & Median & Range & $\begin{array}{l}\text { Mann- } \\
\text { Whitney } \\
\text { U test }\end{array}$ & $P$ value \\
\hline \multirow[b]{2}{*}{1} & \multirow{2}{*}{$\begin{array}{l}\text { Self- } \\
\text { distractio } \\
\mathrm{n}\end{array}$} & Male & 5.0000 & $2.00-8.00$ & \multirow[b]{2}{*}{1236.000} & \multirow[b]{2}{*}{0.922} \\
\hline & & Female & 5.0000 & $2.00-8.00$ & & \\
\hline \multirow[b]{2}{*}{2} & \multirow{2}{*}{$\begin{array}{l}\text { Active } \\
\text { coping }\end{array}$} & Male & 5.0000 & $3.00-8.00$ & \multirow[b]{2}{*}{1234.000} & \multirow[b]{2}{*}{0.910} \\
\hline & & Female & 5.0000 & $2.00-8.00$ & & \\
\hline \multirow[b]{2}{*}{3} & \multirow[t]{2}{*}{ Denial } & Male & 4.0000 & $2.00-8.00$ & \multirow[b]{2}{*}{1070.000} & \multirow[b]{2}{*}{0.207} \\
\hline & & Female & 4.0000 & $2.00-8.00$ & & \\
\hline \multirow[b]{2}{*}{4} & \multirow{2}{*}{$\begin{array}{l}\text { Substanc } \\
\text { e use }\end{array}$} & Male & 2.0000 & $2.00-8.00$ & \multirow[b]{2}{*}{1119.500} & \multirow[b]{2}{*}{0.312} \\
\hline & & Female & 2.0000 & $2.00-8.00$ & & \\
\hline \multirow[b]{2}{*}{5} & \multirow{2}{*}{$\begin{array}{l}\text { Use of } \\
\text { emotiona } \\
1 \text { support }\end{array}$} & Male & 5.0000 & $2.00-8.00$ & \multirow[b]{2}{*}{1229.000} & \multirow[b]{2}{*}{0.883} \\
\hline & & Female & 5.0000 & $2.00-8.00$ & & \\
\hline \multirow[b]{2}{*}{6} & \multirow{2}{*}{$\begin{array}{l}\text { Use of } \\
\text { instrume } \\
\text { ntal } \\
\text { support }\end{array}$} & Male & 4.5000 & $2.00-8.00$ & \multirow[b]{2}{*}{1173.500} & \multirow[b]{2}{*}{0.587} \\
\hline & & Female & 6.0000 & $2.00-8.00$ & & \\
\hline \multirow[b]{2}{*}{7} & \multirow{2}{*}{$\begin{array}{l}\text { Behavior } \\
\text { al } \\
\text { disengag } \\
\text { ement }\end{array}$} & Male & 4.0000 & $2.00-7.00$ & \multirow[b]{2}{*}{1236.000} & \multirow[b]{2}{*}{0.921} \\
\hline & & Female & 4.0000 & $2.00-8.00$ & & \\
\hline \multirow[b]{2}{*}{8} & \multirow[t]{2}{*}{ Venting } & Male & 5.0000 & $2.00-8.00$ & \multirow[b]{2}{*}{1217.500} & \\
\hline & & Female & 4.0000 & $2.00-8.00$ & & 0.819 \\
\hline & Positive & Male & 5.0000 & $2.00-8.00$ & & \\
\hline 9 & reframing & Female & 5.0000 & $2.00-8.00$ & 1154.000 & 0.500 \\
\hline & Planning & Male & 6.0000 & $2.00-8.00$ & & \\
\hline 10 & & Female & 6.0000 & $2.00-8.00$ & 1159.500 & 0.515 \\
\hline & Humor & Male & 5.0000 & $2.00-8.00$ & & \\
\hline 11 & & Female & 4.0000 & $2.00-8.00$ & 1211.000 & 0.782 \\
\hline & Acceptan & Male & 6.0000 & $2.00-8.00$ & & \\
\hline 12 & & Female & 6.0000 & $2.00-8.00$ & 1231.000 & 0.892 \\
\hline & Religion & Male & 4.0000 & $2.00-8.00$ & & \\
\hline 13 & & Female & 4.0000 & $2.00-8.00$ & 1224.500 & 0.855 \\
\hline & Self- & Male & 4.0000 & $2.00-8.00$ & & \\
\hline 14 & blaming & Female & 4.0000 & $2.00-8.00$ & 1063.000 & 0.178 \\
\hline
\end{tabular}




\section{Section 5: Relationship between psychological distress and} coping behaviour of the respondents:

The table 5.1 shows the difference between psychological distress and coping behaviours among male and female respondents. The table indicates that there is high psychological distress in male respondents compared to female respondents while using social networking sites. The MannWhitney $\mathrm{U}$ test computed for this was found to be statistically significant $(\mathrm{U}=891.000, \mathrm{p}=0.013 *)$ differences among the male and female respondents. The table also indicates that there is no difference in the coping behaviour of the respondents. The Mann-Whitney $\mathrm{U}$ test computed for this was found to be no significant $(\mathrm{U}=1141.500, \mathrm{p}=0.454)$ differences among the male and female respondents.

Table 5.1: Psychological distress and coping behaviours among male and female respondents

\begin{tabular}{|c|c|c|c|c|c|c|c|}
\hline \multirow[b]{4}{*}{$\frac{\stackrel{0}{z}}{n}$} & \multirow[b]{4}{*}{ 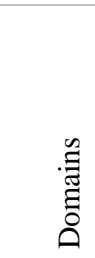 } & \multicolumn{4}{|c|}{ Gender } & \multirow{4}{*}{ 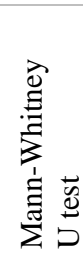 } & \multirow[b]{4}{*}{$\begin{array}{l}\stackrel{0}{\Xi} \\
\frac{\pi}{2} \\
2\end{array}$} \\
\hline & & \multicolumn{2}{|c|}{ Male } & \multicolumn{2}{|c|}{ Female } & & \\
\hline & & \multirow[b]{2}{*}{ 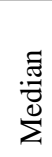 } & \multirow{2}{*}{$\begin{array}{l}\text { Range } \\
\text { Min- } \\
\text { Max }\end{array}$} & \multirow[b]{2}{*}{ 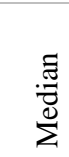 } & \multirow{2}{*}{$\begin{array}{l}\text { Range } \\
\text { Min- } \\
\text { Max }\end{array}$} & & \\
\hline & & & & & & & \\
\hline 1 & DASS & $\begin{array}{l}40 . \\
00\end{array}$ & $\begin{array}{l}04- \\
87\end{array}$ & $\begin{array}{l}29 . \\
50\end{array}$ & $\begin{array}{c}05- \\
92\end{array}$ & $\begin{array}{l}891 . \\
000\end{array}$ & $0.013^{* *}$ \\
\hline 2 & $\begin{array}{l}\text { Brief } \\
\text { COPE }\end{array}$ & $\begin{array}{l}64 . \\
00\end{array}$ & $\begin{array}{l}44- \\
92\end{array}$ & $\begin{array}{l}69 . \\
00\end{array}$ & $\begin{array}{l}34- \\
94\end{array}$ & $\begin{array}{l}1141 . \\
500\end{array}$ & 0.454 \\
\hline
\end{tabular}

Level of Significance: $*=0.05, * *=0.01$ and $* * *=0.001$

\section{IV.DISCUSSION}

The exponential growth of the Internet has caused it to penetrate almost every corner of the world, and for many to impact almost every aspect of daily life across the age span. The study reveals that college students aged range between 18 24 years are having their profiles on various social media websites [19]. With regards to the location of participants, most of the college students i.e., 95\% are from the urban background wherein male are higher than female. Study findings confirms that and identified the study respondents have a monthly family income of Rs less than 50,000 wherein male are more than female college student. The study reveals that majority i.e. $82 \%$ of the college students use social networking sites every day by both genders equally. Study findings indicated that $79 \%$ of college students spend less than 2 hours in a day, almost it has become as part of daily life activity or access frequently, wherein female students access online for using various social networking sites when compares to male college students [23,19 \& 32].

The study investigation revealed that college students encountered different problems wherein male students have reported lack of technical knowledge, lack of security \& privacy problems and not user friendly are the major concerns and some problems are not disclosed by them compare to female students, wherein other studies found that lack of time and poor internet connectivity are major problems [16]. Study found that male students are using social networking sites for the different reasons majorly for friendly communication, for chatting, for entertainment, for sharing photos \& to find information for sharing photos \& picture respectively by male students compare to female. However, in overall, majority of the male respondents uses the social networking sites for different purpose compare to female respondents. Some study's findings say that Internet use, in general, has a positive effect on well-being when it is used for interaction with existing friends [36]. In meta-analysis reported that Internet use is a positive predictor of psychological well-being when it is used for social communication [11].

In the study most of the male students have reported negative experiences from using online social networking site compared to female students. The participants were asked to provide further information about their experience, wherein male students experience reflected like unwanted contact, strangers posting inappropriate or upsetting information on online and female students specified having experiences of online bullying, abusive messages, and harassment from someone of the opposite sex and hacked out of email ID. There is some concern about the risks of online social networking because sites access personal information and privacy-related issues. The use of social networking and other internet sites can become disruptive to daily life or lead to other negative outcomes.

Frightening rates of depression, anxiety, suicidal ideation, and other stress-related problems and explored the outcome of using social networking sites have been found among college students. Different types of Internet use influence the relationship between use and its social and psychological outcomes [36]. It is noted some of the consequences for Internet usage including social isolation, fatigue, and feelings of anger [3]. And found that overall media use, media multitasking was a unique predictor of both depression and social anxiety [22]. The study findings show that there is a significant difference in the psychological distress among college students who are using social networking sites. Log in into online and social networking site usage may lead to psychological conditions like depression, anxiety, and stress. The study found that the mild level of depression is experienced by male college students compare to female college students who are actively using social networking sites. The relationship between the overuse of SNSs and depression may depend to the type of SNS used [13]. and the negative outcomes such as Internet addiction, depression, increased loneliness, procrastination, and sleep loss are commonly seen in the respondents $[1,24]$.

The current study found that a moderate level of anxiety is experienced by male college students compare to female college students who are actively using social networking sites. The decrease in social skills and damage to relationships can lead to depression and anxiety. Participants who used social networking sites to communicate with their parents reported higher levels of loneliness and anxious attachment [9]. The study found that, using blog scores high on social anxiety which tends to make few new friends, communicate 
with fewer existing friends via blogs, and had lower quality of relationship with their existing friends, compared with that score lower on social anxiety. These findings may reflect the difficulties experienced by socially anxious individuals in real life as well. Socially anxious individuals have fewer friends and lower quality of relationship offline due to their anxiety and poor social skills for social interactions offline and online [35].

With respect to the stress level, male college students experienced a mild level of stress wherein female college students experienced a normal level of stress. The study corroborates with findings that students spend more time on the computer, the higher was their stress. And increased use of computers (both in terms of window switching and duration) was associated with increased stress, so the results suggest that type of computer activity may be correlated with lower stress [22].

The researcher found that there are no significant differences in college students who are using social networking sites while adopting coping strategies. And commonly adopted coping behaviours are denial, self-blaming and substance use, etc. Overall, the common coping responses for both genders were similar, such as interpreting sources of stress, taking direct action, and seeking for sharing [34]. The study interviewed with normal adults on a monthly basis and showed that males and females did not significantly differ in their coping behaviours [8]. Further, it was found that males were more likely to adopt direct action as compared with females, who were more likely to use distraction, relaxation, religion, and other coping strategies [33].

\section{Implications of the study:}

- The study attempts to compare SNS usage among college students based on gender which was suggested in previous studies.

- From the study results, it could be reported that college students have both positive and negative impacts concerning the usage of social networking sites.

- Usage of social networking sites became daily life activity since most of the respondents use at least once in a day.

- The study found that those who are spending excessive time on social networking sites are more distressed and prone to get addicted.

- Online negative experiences are reported by high users and many of the users do not want to disclose their negative experiences.

- The overall study shows that male respondents are using a larger amount of SNS and reported higher psychological distress as compared to female respondents.

\section{Limitations of the study:}

- College students are a diverse population ranging in age, ethnicity, beliefs, and living situations and many other factors and the study sample size are small; hence, the study results could not be generalized.
- The correlation between the socio-demographic profile and study variables was not carried out. So, the researcher could not facilitate higher statistics like regression and correlations.

\section{Suggestions for the future study:}

- The same study can be replicated with a larger sample size are to generalize the study.

- A qualitative study can be taken up to understand the different perspectives of different types of social network sites among college students.

- Since the literature is suggesting there is a negative outcome of SNS uses, future interventions-based research could be initiated to address the issues.

\section{CONCLUSION}

Social networking sites are playing major roles in the life of all human populations irrespective of caste and creed. In an advanced lifestyle, it is easy to access everyone, so the impact of SNSs like one coin two sides, positives, and negatives both the effects are influencing users. As many research studies reveal that young populations are the more risk and vulnerable group of people in this current aura. Users should be aware healthy ways of usage and handling ways of hazards. Further research should focus on developing effective evidence-based psychosocial intervention models and to address risk behaviours like online addiction and psychological distress and strengthen adaptive behaviour.

\section{ACKNOWLEDGMENT:}

First and foremost, I would like to thank research guide for his extraordinary support and for sharing their pearls of wisdom during the journey of academic course to successfully complete this research dissertation. And we are also immensely grateful to reviewers for their valuable suggestions and comments on the manuscript.

Conflict of interest: There is no conflict of interest.

Financial Support: Nil

\section{REFERNCES}

[1] Anderson, K. J. (2001). Internet use among college students: An exploratory study. Journal of American College Health, 50(1), 21-26.

[2] Baym, N. K., Zhang, Y. B., Kunkel, A., Ledbetter, A., \& Lin, M. C. (2007). Relational quality and media use in interpersonal relationships. New media \& society, 9(5), 735-752.

[3] Block, J. J. (2008). Issues for DSM-V: Internet addiction.

[4] Bodnar, K., \& Cohen, J. L. (2011). The B2B social media book: Become a marketing superstar by generating leads with Blogging, LinkedIn, Twitter, Facebook, Email, and more. John Wiley \& Sons.

[5] Carver, C. S. (1997). Brief COPE Inventory 1997.

[6] Chou, C., \& Hsiao, M. C. (2000). Internet addiction, usage, gratification, and pleasure experience: the Taiwan college students' case. Computers \& Education, 35(1), 65-80.

[7] Deatherage, S., Servaty-Seib, H. L., \& Aksoz, I. (2014). Stress, coping, and internet use of college students. Journal of American College Health, 62(1), 40-46.

[8] Folkman, S., \& Lazarus, R. S. (1980). An analysis of coping in a middle-aged community sample. Journal of health and social behavior, 219-239. 
[9] Gentzler, A. L., Oberhauser, A. M., Westerman, D., \& Nadorff, D. K. (2011). College students' use of electronic communication with parents: Links to loneliness, attachment, and relationship quality. Cyberpsychology, Behavior, and Social Networking, 14(1-2), 71-74.

[10] Hinduja, S., \& Patchin, J. W. (2010). Bullying, cyberbullying, and suicide. Archives of suicide research, 14(3), 206-221

[11] Huang, C. (2010). Internet use and psychological well-being: A metaanalysis. Cyberpsychology, Behavior, and Social Networking, 13(3), 241-249.

[12] Jacobsen, W. C., \& Forste, R. (2011). The wired generation: Academic and social outcomes of electronic media use among university students. Cyberpsychology, Behavior, and Social Networking, 14(5), 275-280.

[13] Jelenchick, L. A., Eickhoff, J. C., \& Moreno, M. A. (2013) "Facebook depression?" Social networking site use and depression in older adolescents. Journal of Adolescent Health, 52(1), 128-130.

[14] Kalpidou, M., Costin, D., \& Morris, J. (2011). The relationship between Facebook and the well-being of undergraduate college students. CyberPsychology, behavior, and social networking, 14(4), 183-189.

[15] Ko, C. H., Yen, J. Y., Chen, C. S., Chen, C. C., \& Yen, C. F. (2008). Psychiatric comorbidity of internet addiction in college students: an interview study. CNS spectrums, 13(2), 147-153.

[16] Kumar, A., \& Kumar, R. (2013). Use of social networking sites (SNSs): A study of Maharishi Dayanand university, Rohtak, India. Library Philosophy and Practice (e-journal).

[17] Kuppuswamy, S., \& Narayan, P. S. (2010). The impact of socia networking websites on the education of youth. International Journal of Virtual Communities and Social Networking (IJVCSN), 2(1), $67-$ 79.

[18] Lenhart, A., Rainie, L., \& Lewis, O. (2001). Teenage life online: The rise of the instant-message generation and the Internet's impact on friendships and family relationships.

[19] Lenhart, A., Purcell, K., Smith, A., \& Zickuhr, K. (2010). Socia Media \& Mobile Internet Use among Teens and Young Adults. Millennials. Pew internet \& American life project.

[20] Lenhart, A. (2009). Adults and social network websites.

[21] Lovibond, P. F., \& Lovibond, S. H. (1995). The structure of negative emotional states: Comparison of the Depression Anxiety Stress Scales (DASS) with the Beck Depression and Anxiety Inventories. Behaviour research and therapy, 33(3), 335-343.

[22] Mark, G., \& Ganzach, Y. (2014). Personality and Internet usage: A large-scale representative study of young adults. Computers in Human Behavior, 36, 274-281.

[23] Muscanell, N. L., \& Guadagno, R. E. (2012). Make new friends or keep the old: Gender and personality differences in social networking use. Computers in Human Behavior, 28(1), 107-112.

[24] Nalwa, K., \& Anand, A. P. (2003). Internet addiction in students: A cause of concern. Cyberpsychology \& behavior, 6(6), 653-656.

[25] Neilson, L. A., \& Paxton, P. (2010). Social capital and politica consumerism: A multilevel analysis. Social Problems, 57(1), 5-24.

[26] Neelamalar, D. M., \& Chitra, M. P. (2009). Dept. of Media Sciences, Anna University Chennai, India. New media and society: A Study on the impact of socialnetworking sites on indian youth, Estudos em Comunicac ao no6, 125-145.

[27] Niemz, K., Griffiths, M., \& Banyard, P. (2005). Prevalence of pathological Internet use among university students and correlations with self-esteem, the General Health Questionnaire (GHQ), and disinhibition. Cyberpsychology \& behavior, 8(6), 562-570.

[28] Pempek, T. A., Yermolayeva, Y. A., \& Calvert, S. L. (2009). College students' social networking experiences on Facebook. Journal of applied developmental psychology, 30(3), 227-238.

[29] Quan-Haase, A., \& Young, A. L. (2010). Uses and gratifications of social media: A comparison of Facebook and instant messaging. Bulletin of Science, Technology \& Society, 30(5), 350361

[30] Raacke, J., \& Bonds-Raacke, J. (2008). MySpace and Facebook: Applying the uses and gratifications theory to exploring friendnetworking sites. Cyberpsychology \& behavior, 11(2), 169-174.

[31] Sponcil, M., \& Gitimu, P. (2013). Use of social media by college students: Relationship to communication and self-concept. Journal of Technology Research, 4, 1.

[32] Shaw, L. H., \& Gant, L. M. (2004). In defense of the Internet: The relationship between Internet communication and depression, loneliness, self-esteem, and perceived social support. Journal of Obstetrics and Gynaecology Canada, 41(10).

[33] Stone, A. A., \& Neale, J. M. (1980). Development of a methodology for assessing daily experiences. STATE UNIV OF NEW YORK AT STONY BROOK DEPT OF PSYCHOLOGY

[34] Tanck, R. H., \& Robbins, P. R. (1979). Assertiveness, locus of control and coping behaviors used to diminish tension. Journal of Personality Assessment, 43(4), 396-400.

[35] Tian, Q. (2013). Social anxiety, motivation, self-disclosure, and computer-mediated friendship: A path analysis of the social interaction in the blogosphere. Communication Research, 40(2), 237 260

[36] Valkenburg, P. M., \& Peter, J. (2009). The effects of instant messaging on the quality of adolescents' existing friendships: A longitudinal study. Journal of Communication, 59(1), 79-97.

[37] Wang, Q., Chen, W., \& Liang, Y. (2011). The effects of social media on college students

[38] Young, K. S. (1996). Psychology of computer use: XL. Addictive use of the Internet: a case that breaks the stereotype. Psychological reports, 79(3), 899-902. 